\title{
EQUAL PROTECTION AND PROPERTY QUALIFICATIONS FOR ELECTIVE OFFICE
}

Approximately fifty miles west of Detroit lies the "sleepy little town" ${ }^{1}$ of Plymouth, Michigan, whose population is about 9,000. The citizens of Plymouth have proclaimed it "The City of Homes," because eighty to eighty-five per cent of the dwelling units there are privately owned houses. ${ }^{2}$

Peter D. Schweitzer lived in one of the remaining fifteen to twenty per cent dwelling units when he decided to run for city commissioner. Following correct procedure, he submitted a nominating petition with forty signatures to the Plymouth Election Commission. The Commission informed him, however, that his name could not be placed on the ballot because he did not meet all the eligibility requirements as set out in section 4.4 of the city's home rule charter. Although Schweitzer had resided in Plymouth long enough to satisfy its residency requirement, he could not fulfill the requirement that the holder of every elective office "shall also have been, for a period of two years, prior to the date of his election . . . to office, the owner of property located within and assessed for taxes by the city." 3

Schweitzer and several citizens who had signed his petition set out to challenge the constitutionality of this qualification and petitioned for a writ of mandamus ordering the city clerk to place his name on the ballot. This challenge was unsuccessful in the Michigan Supreme Court, which held in Schweitzer v. Clerk for City of Plymouth ${ }^{4}$ that the equal protection clause of the United States Constitution was not violated by a qualification which prevented persons who had not been assessed for property taxes from holding public office. ${ }^{5}$

\section{Present Status of Property Qualifications}

In the first third of the century, several state supreme courts reviewed similar qualifications for public office and found them valid

1 Schweitzer v. Clerk for City of Plymouth, 381 Mich. 485, 493, 164 N.W.2d 35, 39 (1969), petition for cert. filed, 37 U.S.L.W. 3462 (U.S. May 2, 1969) (No. 1349, 1968 Term; renumbered No. 95, 1969 Term).

2 Appendix to Brief for Appellant at 23a, Schweitzer v. Clerk for City of Plymouth, 381 Mich. 485, 164 N.W.2d 35 (1969).

3 Schweitzer v. Clerk for City of Plymouth, 381 Mich. 485, 488 n.1, 164 N.W.2d 35, 37 n.1 (1969), quoting City of Plymouth Charter \$4.4.

4 Id. at 485,164 N.W.2d at 35 (1969).

5 Although the plaintiff is a minister, issues of religious liberty were raised by neither counsel. Plaintiff's counsel alluded to clergymen simply as a group often disadvantaged by the property qualification, noting that "[a]s a minister, Reverend Schweitzer was furnished residential quarters by his church . . "Brief for Appellee at 9, Schweitzer v. Clerk for City of Plymouth, 381 Mich. 485, 164 N.W.2d 35 (1969). 
when not in conflict with specific provisions in state constitutions. ${ }^{6}$ In 1937, for example, the New York Court of Appeals approved the state's property requirements. ${ }^{7}$ Very recently, however, in Landes $v$. Town of North Hempstead, ${ }^{8}$ the New York court overruled its earlier findings of constitutionality in light of " $[\mathrm{r}]$ ecent developments in constitutional law, as well as changes in the pattern of town and suburban living ...." The New York court found that social changes had eliminated any significant differences between property owners and renters for purposes of office holding, leaving no justification for the qualification. ${ }^{10}$ Then, analogizing to recent Supreme Court decisions prohibiting restrictions on the franchise based on wealth ${ }^{11}$ or place of residence, ${ }^{12}$ the court held that a property qualification could not be permitted to restrict the ability of electors to vote for anyone they might choose. ${ }^{13}$ The Michigan Supreme Court in Schweitzer disputed both these propositions, denying that social changes affecting the state of New York had reached Plymouth, or that the voting cases provided analogies for ruling on office-holding qualifications. ${ }^{14}$ These disagreements stem from different judgments the courts made about their ability to review legislative determinations on the subject of qualifications for public office.

More than one standard has been used by the Supreme Court in determining whether state legislation has violated the equal protection clause. ${ }^{15}$ The basic criterion for constitutionality is that classifications established by the states "must always rest upon some difference which bears a reasonable and just relation to the act in respect to which the classification is proposed . . . "16 In addition, classifications must serve some legitimate state purpose. ${ }^{17}$ The Supreme Court has given the states every benefit of the doubt in applying this test, especially in cases involving economic regulation. ${ }^{18}$ But it has also devised a more stringent test for classifications based on certain "suspect" character-

6 See State ex rel. Workman v. Goldthait, 172 Ind. 210, 87 N.E. 133 (1909) (qualification held valid); Powell v. Hart, 132 La. 287, 61 So. 233 (1913) (qualification held invalid); State ex rel. Fletcher v. Ruhe, 24 Nev. 251,52 P. 274 (1898) (valid); State ex rel. Thompson v. McAllister, 38 W. Va. 485, 18 S.E. 770 (1893) (valid).

7 See Becraft v. Strobel, 274 N.Y. 577, 10 N.E.2d 560 (1937).

820 N.Y.2d 417, 231 N.E.2d 120, 284 N.Y.S.2d 441 (1967).

9 Id. at 419,231 N.E.2d at 121, 284 N.Y.S.2d at 443.

10 Id. at 421, 231 N.E.2d at 122, 284 N.Y.S.2d at 444.

11 See Harper v. Virginia Bd. of Elections, 383 U.S. 663 (1966) (state poll tax held unconstitutional).

12 See, e.g., Reynolds v. Sims, 377 U.S. 533 (1964).

1320 N.Y.2d at 421,231 N.E.2d at 122, 284 N.Y.S.2d at $444-45$.

14 See 381 Mich.' at 491-94, 164 N.W.2d at 38-39.

15 See Tussman \& tenBroek, The Equal Protection of the Laves, 37 CALIF. L. REv. 341, 353 (1949) ; Note, Equal Protection and the Indigent Defendant: Griffin and Its Progeny, 16 Stan. L. Rev. 394, 399 (1964).

16 Gulf, C. \& S.F. Ry. v. Ellis, 165 U.S. 150, 155 (1897).

17 See, e.g., Truax v. Raich, 239 U.S. 33, 42 (1915).

18 See, e.g., Lindsley v. Natural Carbonic Gas Co., 220 U.S. 61 (1911). 
istics, ${ }^{19}$ or which result in deprivation of certain "fundamental rights." 20 Such a classification, "even though enacted pursuant to a valid state interest, bears a heavy burden of justification . . . and will be upheld only if it is necessary, and not merely rationally related, to the accomplishment of a permissible state policy." 21

Therefore, even though a property qualification can withstand the above mentioned reasonable relationship test, it may demand analysis under the latter, and more stringent, "necessity" test. Three recent cases suggest that the property qualifications involved in Schreitzer and Landes may require this type of additional analysis and justification. In Harper v. Virginia Board of Elections, ${ }^{22}$ the Court added classifications based on wealth to the "suspect" group. In Williams v. Rhodes, ${ }^{23}$ the Court held that state laws which effectively prevent a political party from appearing on the ballot infringe upon the "fundamental rights" of voting and political association. Finally, in Kramer v. Union Free School District, ${ }^{24}$ the Court struck down a state law which prevented an otherwise qualified bachelor from voting in a school district election, because he neither had a child attending the local schools nor owned (or leased) taxable property. Therefore, if it can be demonstrated that the right to vote effectively and the right to run for public office are fundamental rights, and, in turn, these rights are impinged upon by the property qualification in the absence of a compelling state interest, then the constitutional requisite of equal protection has been violated. However, it is difficult to make this type of judgment. The scope of the three decisions mentioned above is as yet undefined. Indeed, the Court has been criticized for failing to elaborate a rational standard, or even points of reference, by which to judge what activities are to receive favored treatment as "fundamental rights" under the equal protection clause. ${ }^{25}$ The Schweitzer court, however, did not even consider whether this higher standard should be applied. Neither, in fact, did it bother to apply the basic reasonable relationship test. It is the contention of this Comment that if it had applied either test, the Schweitzer court could not have concluded that Plymouth's property qualification was valid.

19 See McLaughlin v. Florida, 379 U.S. 184 (1964); Oyama v. California, 332 U.S. 633 (1948) ; Korematsu v. United States, 323 U.S. 214 (1944) (dictum); Truax v. Raich, 239 U.S. 33 (1915).

20 See Reynolds v. Sims, 377 U.S. 533 (1964) (voting) ; Skinner v. Oklahoma ex rel. Williamson, 316 U.S. 535 (1942) (procreation); Truax v. Corrigan, 257 U.S. 312 (1921) (conducting business); Truax v. Raich, 239 U.S. 33 (1915) (working).

21 McLaughlin v. Florida, 379 U.S. 184, 196 (1964) ; see Wesberry v. Sanders, 376 U.S. 1, 17-18 (1964).

22383 U.S. 663 (1966) (state poll tax held unconstitutional).

23393 U.S. 23 (1968).

24395 U.S. 621 (1969).

25 See Harper v. Virginia Bd. of Elections, 383 U.S. 663, 670 (1966) (Black, J., dissenting); Cox, Foreword: Constitutional Adjudication and the Promotion of Human Rights, 80 HaRv. L. REv. 91, 95 (1966). 


\section{Property Qualifications Submitted to the Reasonable Relationship Test}

The Michigan court began its analysis with the assumption that if a regulation does not interfere with the personal liberty of citizens or the enjoyment of their property, "the same standards of reasonableness and relationship to purpose as are found in cases dealing with regulations under the police power" need not be applied. ${ }^{28}$ Admittedly, voting in municipal elections and running for municipal offices are "political rights," ${ }^{27}$ extended by the sovereign, and consequently the due process clause of the United States Constitution does not protect a personal or property right to hold office. ${ }^{28}$ However, once the franchise has been extended to some citizens, or municipal offices have been established, the equal protection clause does not permit arbitrary exclusions from these political rights. ${ }^{29}$ Indeed, for the question of voting the Supreme Court has established stricter standards to judge the validity of a discriminatory classification.

Statutes granting the franchise to residents on a selective basis always pose the danger of denying some citizens any effective voice in the governmental affairs which substantially affect their lives. Therefore, if a challenged state statute grants the right to vote to some bona fide residents of requisite age and citizenship and denies the franchise to others, the Court must determine whether the exclusions are necessary to promote a compelling state interest. ${ }^{30}$

From its original erroneous assumption that the reasonable relationship test need not be applied where the state's police power is not involved ${ }^{31}$ - an assumption unsupported by cases-the Schweitzer court concluded that qualifications for office-holding may be "arbitrary" or "parochial and intolerant," as long as they have been determined by a majority of the voters. ${ }^{32}$ As examples of such "essentially arbitrary" qualifications, the court cited the provisions in the United States Constitution which set minimum age limits for the President and congressmen ${ }^{33}$ as well as state requirements for the minimum and maximum age limits which exist for most state offices. ${ }^{34}$ Having mature officials, however, is a legitimate governmental purpose, and it can reasonably be

26381 Mich. at 492,164 N.W.2d at 38.

27 Note 54 infra \& accompanying text.

28 See, e.g., Taylor v. Beckham, 178 U.S. 548 (1900).

${ }^{29}$ See Harper v. Virginia Bd. of Elections, 383 U.S. 663, 665 (1966) ; Snowden v. Hughes, 321 U.S. 1, 11 (1944) (dictum).

30 Kramer v. Union Free School Dist., 395 U.S. 621, 626-27 (1969) (footnote omitted).

31 Note 26 supra \& accompanying text.

32381 Mich. at 493, 164 N.W.2d at 39.

33 For these provisions, see U.S. Const. art. I, §§ 2, 3 ; art. II, §1.

34381 Mich. at 492,164 N.W.2d at 38. 
believed that a candidate's age is directly related to his maturity. Admittedly, if the Michigan court had scrutinized Plymouth's property qualification on the basic level of reasonable relationship, it probably could have found some rational reasons for the property requirement. The traditional justification for property requirements, traceable to colonial America, is that property holders have a greater "stake in society"; ${ }^{35}$ presumably they have a greater "interest in the welfare and prosperity of their permanent dwelling place." 36 The city of Plymouth contended that since the city commissioners have the power to borrow money secured by property tax revenues and to tax property in order to operate the local government, the qualification was necessary to protect the "citizens of the City of Plymouth, in and the preservation of their property." 37 This argument assumes, of course, that the taxpayers will be more economical in administering town affairs because their own money is being spent.

The Landes court challenged similar arguments when it stated:

[W] fail to see how . . . qualities of carefulness and frugality were ever the monopoly of those owning real property. . . In a society such as ours, characterized by its "mobility" and "anonymity" [citation omitted], a landowner is no more likely to be permanently established in a townand, by that token, better qualified to govern-than one who is not a property owner. ${ }^{38}$

Judgments of this type are particularly vulnerable to attack. The court here is really setting up its own evaluation of society as the only reasonable one which a legislative body may hold. Even if these generalizations are valid for most of America, may they be used by courts to strike down legislation for the sleepy little towns such as Plymouth, Michigan? It must be noted that the New York and Michigan courts were reviewing laws of different scope. In Schweitzer, the Michigan court upheld a provision enacted under the broad mandate of a home rule charter, which applied only to the locality involved. On the other hand, the Landes court struck down a provision of New York's

35 Brown, Reinterpretation of the Formation of the American Constitution, 42 B.U.L. REV. 413,421 (1962). Brown makes clear, however, that property qualifications did not disenfranchise most colonists.

The amount of property required for voting in the colonies was not sufficient to exclude any but the very poorest men, if those. The $40 \mathrm{~s}$. freehold required for the vote in some colonies meant real estate that would rent for $40 \mathrm{~s}$. a year, the equivalent of ten day's [sic] wages for a carpenter. By comparison, ten day's wages for a carpenter today would not even pay a year's rent on a single room.

Id. 422.

36 State ex rel. Thompson v. McAllister, 38 W. Va. 485, 494, 18 S.E. 770, 773 (1893), quoted in Schweitzer v. Clerk for City of Plymouth, 381 Mich. 485, 493 n.6, 164 N.W.2d 35, 39 n.5 (1969).

37 Brief for Appellant at 14, Schweitzer v. Clerk for City of Plymouth, 381 Mich. 485,164 N.W.2d 35 (1969) (emphasis in original).

3820 N.Y.2d at $420-21,231$ N.E.2d at 122, 284 N.Y.S.2d at 444. 
Town Law which applied to urbanized, suburbanized, and rural communities. ${ }^{39}$ Landes, however, was not couched in self-limiting terms. The opinion's expansive focus implies that no community could validly establish a property qualification, even if the qualification extended no further than the town lines.

The Landes majority found precedent for this evaluation in the Harper case, where the Supreme Court held that a poll tax on state elections violated the equal protection clause. Mr. Justice Douglas writing for the Court stated: "Voter qualifications have no relation to wealth nor to paying or not paying this or any other tax." 40 This statement should be even more applicable to Plymouth's requirement than to the New York Town Law involved in Landes. While New York simply demanded that public officials be freeholders, ${ }^{41}$ the Plymouth ordinance demands that they pay real or personal property tax for two years prior to election. ${ }^{42}$ However, in Harper the Court was dealing with the fundamental right of voting, which biased its factual determinations against the state; as yet, running for office has not been explicitly established as such a right. The Landes court overlooked the additional consideration that certain qualifications may be more relevant to an official's task than to a voter's. The representative who actually handles tax money may encounter temptations, and therefore he may need a higher standard of frugality than the voter (who probably endorses economical government whether or not he pays taxes). Finally, although a poll tax simply tests a voter's wealth, a property requirement may test a candidate's stability and interest in the community. Even wealthy people who have their holdings in forms not taxable by the city will be ineligible for office. ${ }^{43}$ Thus the Landes majority was begging important factual questions when it based its findings on Harper's rejection of wealth as a criterion for voting.

No doubt there are many arguments, aside from the one raised in Landes, which may overwhelm the traditional reasoning that serves as a premise for property qualifications. Renters suffer from property taxes indirectly through rent increases. Furthermore, if their poverty forces them to rent, they have as much of a stake in the prosperity of their community as propertied residents; having too little money to be mobile, they are the first to suffer during hard times. Also, because they have as much to gain from fiscal responsibility as do other members

39 N.Y. Town LAw \$ 23, 23-a (McKinney 1965).

40383 U.S. at 666 (1966).

41 N.Y. Town LAw \$\$23, 23-a (McKinney 1965).

42381 Mich. at 488, 164 N.W.2d at 36.

43 See id. at 497, 164 N.W.2d at 41 (dissenting opinion). Although in practice any wealthy person who wished to become city commissioner could purchase 2 sewing machines, for example, thereby obtaining the necessary property qualification, he would be disadvantaged by the 2 year waiting period during which he would have to pay taxes on that property. See MICH. Comp. LAws ANN. $\$ 211.9$ (1967) for a list of personal property exempted from the property tax. Most property which the average renter uses for personal consumption is exempted. 
of the community, renters may be just as interestd as homeowners in the use of tax money. Renters may even be as interested as homeowners in keeping taxes low, in order to prevent the tax base from moving elsewhere. Finally, citizens may not always act strictly on the basis of their own monetary interests, and as a result the interests of propertied and nonpropertied citizens need not be antithetical. But are these propositions so well established that a town cannot reasonably conclude to the contrary about its own population? Assuming arguendo that there is no fundamental right involved which would weight the reasonableness standard in favor of the deprived minority, there may be a more fruitful method of measuring property qualifications by the reasonable relation standard.

As early as 1885, the Supreme Court, in discussing aspects of the municipal police power, distinguished two types of regulations. One regulation "may press with more or less weight upon one than upon another, but [it is] designed, not to impose unequal or unnecessary restrictions upon any one, but to promote, with as little individual inconvenience as possible, the general good." 44 The other type is simply "[c]lass legislation, discriminating against some and favoring others ... " 45 This reasoning is, of course, equally applicable to qualifications for a candidate. If a regulation which works to the detriment of one class is imposed simultaneously with a regulation which does not, and both regulations serve essentially the same purpose, we may assume that the first regulation is an unnecessary inconvenience for members of the disadvantaged group. Moreover, we may suspect that its purpose is simply to give the favored group an improper advantage.

Recently, the Supreme Court in Hunter v. Erickson ${ }^{46}$ used analysis consistent with the above approach ${ }^{47}$ to invalidate a referendum procedure which made it especially difficult for a city to pass a fair housing ordinance protecting racial and religious minorities. The Court found that the usual referendum procedures, which applied to fair housing ordinances designed to protect any group, were sufficient to serve the purposes of "mov[ing] slowly in the delicate area of race relations .... The amendment was unnecessary either to implement a decision to go slowly, or to allow the people of Akron to participate in that decision." 48 Similarly, in Carrington $v$. Rash, ${ }^{49}$ the Supreme Court held that a state could not bar all servicemen from voting in its elections, even if it reasonably feared their transiency and consequent political views, as long as it could rely on its general requirement that all voters be bona fide residents.

44 Barbier v. Connolly, 113 U.S. 27, 31-33 (1885) (emphasis added).

$45 \mathrm{Id}$. at 32 .

46393 U.S. 385 (1969).

$47 \mathrm{See}$ id. at 393-96 (Harlan, J., concurring).

48 Id. at 392.

49380 U.S. 89 (1965). 
In the instant case, several regtulations governing the qualifications and permissible activities of city commissioners already exist in Plymouth. These regulations make the taxable property qualification unnecessary. First, Plymouth's requirement that all office holders must have been residents for two years prior to their election counters the complaint that renters are uninterested transients. Renters who have lived in the city for two years have sufficiently demonstrated that they are willing to take the responsibility for their votes, and to live with the consequences. They certainly do not reach the depths ascribed to them in a quote cited by the majority in Schweitzer as a possible rationale for property qualifications. This description likens renters to "Bedouins of the plains," who " "neath the shadows of night . . . can fold their tents, and silently steal away" ${ }^{50}$ after they have wrecked the fortunes of the frugal property owners.

Second, a locally imposed ceiling on property tax assessments meets the argument that only propertied commissioners will be restrained in exercising their power to raise and spend tax money to which they must contribute. Section 10.5 of the Plymouth charter limits the assessment rate for municipal purposes to one and one-half per cent, subject both to increases when approved by a majority of the electors and to state provisions controlling redemption of municipal bonds. $^{51}$ In addition, although Michigan requires unlimited assessments for paying off municipal indebtedness, the Plymouth charter limits the amount of net bonded indebtedness which may be incurred. ${ }^{.2}$ Thus unpropertied commissioners cannot spend blithely in the knowledge that they can always raise more tax money from propertied citizens to meet their expenses.

By these provisions, Plymouth's property holding majority has insured that their tax money will be spent economically. Therefore, the added property qualification for commissioners unfortunately appears as an attempt by the property holders to insure that all decisions by the commission will be made in the property owners' interests, not in the interests of the community as a whole. Although economy is a legitimate governmental purpose, designed to advantage no particular group, government in favor of propertied citizens is not. ${ }^{53}$ Thus the Plymouth property qualification is placed in jeopardy when scrutinized under the basic reasonable relationship test. The qualification serves few purposes besides those which are otherwise insured, while it raises unfortunate suspicions about the motivation behind it.

50 State ex rel. Thompson v. McAllister, $38 \mathrm{~W}$. Va. 485, 495, 18 S.E. 770,773 (1893), quoted in 381 Mich. at 493 n.6, 164 N.W.2d at 39 n.5.

51 Appendix to Brief for Appellant at 11a, 31a, Schweitzer v. Clerk for City of Plymouth, 381 Mich. 485, 164 N.W.2d 35 (1969).

52 Id. at $35 \mathrm{a}$.

53 Notes 44-49 supra \& accompanying text. 


\section{A Stricter Standard for Office-Holding Qualifications}

Whatever doubt exists about the validity of property qualifications under the reasonable relationship test is dispelled in favor of unpropertied citizens if the stricter standard for fundamental rights is applied. Whether this standard should be applied here depends upon the resolution of two separate but integrally related issues that were merged in the Schweitzer case. The first, and the most obvious, is whether the right to run for elected office is indeed a fundamental right which can be restricted only by a compelling state interest. ${ }^{54}$ The second issue, one which does not surface immediately, is whether the residents of Plymouth, by a majority vote, can constitutionally impose restrictive qualifications on certain offices when such qualifications affect only a portion of an otherwise qualified body of persons.

The Michigan court, combining these two issues, did not find holding office fundamental in any sense; rather, the court found that establishing qualifications for public office, unlike establishing voting qualifications, is a "political decision." ${ }^{55}$ The court explained that "[i]n a democracy, the majority rules. . . . The majority of the people of Plymouth have established the qualifications for their city commissioners." 56 Presumably, then, once a majority of voters has coalesced, free of unnecessary voting qualifications, they should be able to choose the qualifications for public office which suit them. As the court stated: "It is peculiarly so, since the same majority which establishes the qualification elects the office-holders. If a candidate has the votes to be elected, then he has the votes to change the eligibility requirement; and if he doesn't have the votes to change the qualification, then he does not have the votes to be elected." 57 Such assertions by the court are assailable both factually and constitutionally.

In addressing the candidacy issue, we begin with the premise that a candidate's right to run for elected office is a corollary to the right to vote for that candidate. When only one candidate represents the political views of a segment of the electorate, and he is prevented from running, then those voters who support him have lost an opportunity to cast their vote effectively. This problem arose in Williams $v$. Rhodes ${ }^{58}$ when George Wallace's American Independent Party was denied a place on Ohio's presidential ballot.

Mr. Justice Black's plurality opinion in that case held first "that no State can pass a law regulating elections that violates the Fourteenth Amendment's command that 'No State shall ... deny to any person

54 Cf. Williams v. Rhodes, 393 U.S. 23, 31 (1968), quoting NAACP v. Button, 371 U.S. 415,438 (1963).

65 381 Mich. at 492, 164 N.W.2d at 39.

$56 I d$.

$67 I d$.

88393 U.S. 23 (1968). 
... the equal protection of the laws." "59 The opinion then focused on the question whether a state law requiring, inter alia, a new political party to present a petition for position on the ballot which bore signatures of "qualified electors totaling $15 \%$ of the number of ballots cast in the last preceding gubernatorial election" " 60 violated the equal protection clause. Mr. Justice Black found that the law burdened both the right of political association and the right to vote "effectively." Since the state could show no compelling interest justifying these burdens, the Court found the law unconstitutional in violation of the fourteenth amendment. Mr. Justice Douglas concurred in the plurality opinion, but stressed that any compelling interest of the state was irrelevant. ${ }^{61}$

The meaning of Mr. Justice Black's reference to the right to vote "effectively" was perhaps clarified by Mr. Justice Douglas when he stated, "I would think that a State has precious little leeway in making it difficult or impossible for citizens to vote for whomsoever they please ...." ${ }^{2}$ Although Mr. Justice Harlan concurred only in the result, because he relied on the due process clause of the fourteenth amendment, he also implied that the right of political association embraced a right of candidacy. He stated that Ohio, "by denying the appellants any opportunity to participate in the procedure by which the President is selected, . . . has eliminated the basic incentive [of all political parties]." 63 The incentive is the election of the party's candidate. Restricting candidacy, at least in the case of a charismatic candidate appealing to a disenchanted electorate, restricts effective political organization, a fundamental right. ${ }^{64}$ Demanding a compelling state interest to restrict effective political organization without demanding a similar interest in restricting candidacy abandons the safeguards on the initial right of political association.

It is now necessary to apply the principles of effective political organization and its corollary, the right to run for elected office, to Plymouth, Michigan. Factually, there is no reason to believe that property holders would not find attractive a candidate willing to represent their interests, but unable to satisfy the property-holding requirement. A wealthy person, for example, who might appeal to propertied interests, might simply be unable to put his holdings in taxable forms soon enough before the election to qualify for the ballot. ${ }^{65}$ Thus, even though the home-owning majority might fear unpropertied persons as

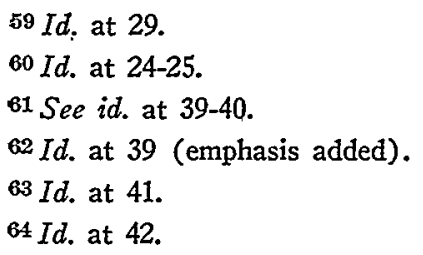

65 A candidate's property must be taxed for 2 years before he becomes eligible for elective office. 381 Mich. at 488 n.1, 164 N.W.2d at 37 n.1 (1969). 
a class, and hence be unwilling to change the general property qualification, it might still desire to support one particular unpropertied candidate.

More important, free access to public office is not merely a political question ${ }^{66}$ but is fundamental to American democracy. Although, as Schrueitzer correctly states, "[A] minority cannot have an equal right to govern," 67 a minority must have an equal chance to participate in government, regardless of whether it prevails. ${ }^{88}$ The promise of democracy is that today's minorities, through rational persuasion and political maneuvering, can become tomorrow's majority. This promise is dashed if today's majority biases the structure of governmental institutions in favor of its own self-perpetuation. ${ }^{\text {.9 }}$

Office-holding qualifications as well as voting qualifications may produce such structural biases. Plymouth's property qualification, for example, raises the danger that the city commissioners will often favor property-holding citizens. Although all citizens are treated alike in being prevented from voting for unpropertied candidates, it is likely that the property-holding majority can find effective spokesmen from the propertied candidates. The unpropertied citizens, on the other hand, are denied many of their most responsive representatives when they cannot choose candidates who share their position in the community. Voters may well feel that they are best represented by men who can identify with, and therefore articulate, their problems. They may find a man of their own circumstances more charismatic, and as a result he may be more effective in precipitating political organization and bargaining strength within the group. The voters who enacted the property qualification, however, must have presumed that representatives with property would not act in accordance with the interests of their unpropertied constituents. Otherwise, there would have been no reason for the enactment since other provisions insure economical government. ${ }^{70}$ This assumption is not unwarranted. In theory every representative must respond to the needs of his constituency, or he will be in danger at the next election. However, if no candidate represents unpropertied interests, the unpropertied minority is left with no alternative choice. Their representatives have no incentive to respond to their needs. Thus the process of rational persuasion and political maneuvering which shifts legislative majorities is distorted when participants do not represent unpropertied interests as well as they represent propertied interests.

${ }^{66}$ See generally Baker v. Carr, 369 U.S. 186, 218 (1962).

67381 Mich. at 493, 164 N.W.2d at 39.

${ }^{68}$ Cf. Lucas v. Forty-Fourth Gen. Assembly, 377 U.S. 713, 736-38 \& n.31 (1964) (majority cannot approve apportionment of state senate giving equal representation to minority interests). See generally Hunter v. Erickson, 393 U.S. 385, 392 (1969): "The sovereignty of the people is itself subject to those constitutional limitations which have been duly adopted and remain unrepealed." Text accompanying notes 77-82 infra. 69 Cf. Hunter v. Erickson, 393 U.S. 385, 393-96 (1969) (Harlan, J., concurring). 70 Notes $50-52$ supra \& accompanying text. 
Even if Williams $v$. Rhodes ${ }^{71}$ did not establish a fundamental right to hold public office, ${ }^{72}$ it did hold that a restriction on who may run for office simultaneously restricts the ability of each individual to vote for the candidate of his choice, thereby impinging upon another fundamental right. Since Plymouth's property qualification allows propertied, but not unpropertied, voters to elect officials who share their interests, the votes of unpropertied citizens are diluted and "ineffective" in relation to the others. ${ }^{73}$ Of course every restriction on who may run for public office is not thereby prohibited, just as every restriction on the franchise is not prohibited. ${ }^{74}$ But in determining which restrictions are constitutional, the test is not simply whether a reasonable relationship exists between the classification and the purposes of the legislation, but, since important rights are involved, whether any "compelling state interest" 75 justifies the deprivation suffered by some group or individuals. Here, the state has failed to show any compelling interest that could justify the property requirement. Plymouth's limitations on the city council's power to incur debts removes the objection that unpropertied persons will improvidently expend tax revenues. The two-year residency requirement assures that candidates have a personal interest in the town's welfare.

However, one last distinction remains. Williams dealt with political parties and not individual candidates. Is this distinction sufficient to preclude application of Williams to this case? In Williams, the requirements for being placed on the ballot effectively applied to candidates only if they were not affiliated with one of the two major political parties. ${ }^{76}$ Any candidate unacceptable to these two parties was disadvantaged because he had to form another party, with the attendant overwhelming burdens. Thus the candidates and voters in Williams came to court as members of particular political parties, and the Court could emphasize the fact that their desire to organize had been thwarted. In Schweitzer, however, the candidate was not disadvantaged because of any party affiliation; and the voters who sued with him had not formed any organization to further his campaign. The difference, nonetheless, may be one of form and not substance. The only reason for founding the American Independent Party, the party involved in Williams, was to further the candidacy of George Wallace. There was no intent to establish a party organization which would present candi-

71393 U.S. 23 (1968).

72 When Mr. Justice Black demanded a compelling state interest to restrict the right of association, he relied not on previous voting cases but on NAACP v. Button, 371 U.S. 415 (1963). See Williams v. Rhodes, 393 U.S. 23, 31 (1968). His reluctance to base the right of association on voting cases suggests that political association rather than candidacy was the crucial issue in Williams, and therefore the implied right of candidacy could be illusory.

73 See id. at 31 ; cf. Reynolds v. Sims, 377 U.S. 533, 555 (1963).

74 See Lassiter v. Northampton County Bd. of Elections, 360 U.S. 45 (1959).

75 Williams v. Rhodes, 393 U.S. 23, 31 (1968).

76 Id. at 25 . 
dates of the American Independent Party at all levels of government. By extension, once a candidate has achieved considerable political support, organized or not, disqualifying him denies political expression to his supporters, who are prevented from rallying around their man and from achieving effective political organization.

Even if the right to run for political office is not found to be fundamental, it would appear that the right to vote is limited by the Plymouth property qualification, and, therefore, the state must demonstrate a compelling interest to justify this limitation. Since Plymouth's city council is restricted in its power to spend tax revenues, and the residency requirement prevents control by transients, the only possible compelling interest is that a majority of the residents of the community chose to qualify the eligibility requirements for elective office.

The ability of a majority of the electorate to burden the voting rights of a minority was considered by the Supreme Court in Lucas v. FortyFourth General Assembly. ${ }^{77}$ The Court faced the issue whether a majority of Colorado's voters could approve an apportionment scheme for the state senate based on regions rather than population. The Court held that apportionment of both houses of the legislature must be based on population. The approved scheme deviated so far from a population basis that it violated the equal protection clause. ${ }^{78}$ The Court stated:

An individual's constitutionally protected right to cast an equally weighted vote cannot be denied even by a vote of a majority of a State's electorate . . . Manifestly, the fact that an apportionment plan is adopted in a popular referendum is insufficient to sustain its constitutionality . . . ${ }^{79}$

Mr. Justice Stewart in dissent strongly denied that Colorado's apportionment scheme was other than representative government. $\mathrm{He}$ would not have set aside the state's plan if Colorado could reasonably justify it by demonstrating that the apportionment plan furthered a rational, legislative purpose without frustrating majority will. ${ }^{80}$

Applying Lucas to the instant case, we note that malapportionment is strikingly similar to restrictions on candidates. Both decrease the effectiveness of the votes of a certain segment of the electorate; the individual in a malapportioned district casts a diluted vote while the unrepresented voter wastes his vote on unresponsive candidates. In the absence of other compelling interests, the argument that a majority of Plymouth's residents can render ineffective the fundamental right of the unpropertied minority "to cast their votes effectively" ${ }^{11}$ falls before Lucas. Even if Mr. Justice Stewart's test of rational legislative

77377 U.S. 713 (1964).

78 Id. at 735 .

$79 \mathrm{Id}$. at 736 .

$80 \mathrm{Id}$. at 753-54.

81 Williams v. Rhodes, 393 U.S. 23, 30 (1968). 
purpose is utilized, the Michigan court conceded that the property qualification may be "parochial and intolerant." 82 Consequently, Plymouth's property qualification can muster no compelling interest to justify the restrictions it places on the voting ability of unpropertied residents.

\section{ConcLusion}

A close analysis of the factual situation in Schweitzer demonstrates that the property qualification ordinance is a violation of equal protection. Since there are already nondiscriminatory ordinances in the township which effectively achieve the supposed purposes of the property qualification requirement, there appears to be no other rational reason for the ordinance except to disadvantage renters. Moreover, strong arguments can be made to show that this property qualification would fall when analyzed under the stricter "necessity" test. In light of recent Supreme Court decisions, the right to run for elective office and/or the right to vote effectively should be considered fundamental rights which can be subordinated only to a compelling state interest. Again, due to the effectiveness of the other nondiscriminatory ordinances, the property qualifications cannot possibly serve any compelling state interest. Hence, the property qualification should fall again. Hopefully, courts that deal with situations similar to that found in Schweitzer will attempt a more thorough analysis than the superficial gloss developed by the Michigan Supreme Court.

82381 Mich. at 493,164 N.W.2d at 39. 